\title{
CHARACTERIZATION OF EQUILIBRIUM CONDITIONS OF ADSORBED SILICA-GEL/WATER BED ACCORDING TO DUBININ-ASTAKHOV AND FREUNDLICH
}

\author{
M. R. A. Afonso ${ }^{\text {a }}$ | ABSTRACT \\ and V. Silveira $\mathbf{J r}^{\text {b }}$ \\ a,b Universidade Estadual de Camapinas \\ Faculdade de Engenharia de Alimentos \\ Departamento de Engenharia de Alimentos \\ Bairro Barão Geraldo \\ CP. 6121, CEP 13083-862, \\ Campinas, SP Brasil \\ marcos@fea.unicamp.br \\ vivaldo@fea.unicamp.br \\ Systems of adsorption have been studied as an alternative for the cooling systems for saving \\ electrical energy. The main advantage is the heat as the driving sources, for example, hot \\ water or waste heat, widely used in the industries, and solar energy. The pair adsorbent/ \\ adsorbate determines the behavior of these systems. Therefore, the knowledge of the \\ equilibrium conditions between the adsorbent and the adsorbate is very important. The pair \\ silica gel/water has the advantage of exploiting low-temperature heat sources. In this paper, \\ the equilibrium conditions of the pair silica gel/water were investigated and the data were \\ used to identify the coefficients of Dubinin-Astakhov equation and Freundlich equation. \\ The experiments consisted of measuring temperature and pressure for different adsorbed \\ mass of water in the adsorbent (silica gel). The amount of adsorbed mass $(\mathrm{kg})$ per adsorbent \\ mass (kg) used were: 0.007, 0.013, 0.024, 0.047, 0.092, 0.162 and 0.209. Both equations \\ showed good agreement with experimental data, the coefficients of regression $\left(\mathrm{R}^{2}\right)$ were \\ 0.991 on the Dubinin-Astakhov equation and 0.993 for the Freundlich equation. \\ Keywords: Adsorption, silica-gel, silica-gel/water
}

\section{NOMENCLATURE}

B constant of the pair adsorbent/adsorbate

$\beta \quad$ affinity coefficient of adsorbate

D affinity coefficient of the pair adsorbent/ adsorbate, is the relation between $\mathrm{B}$ e $\beta^{n}$

$\mathrm{P} \quad$ system pressure, $\mathrm{kPa}$

$\mathrm{P}_{\text {sat }}$ saturation pressure of adsorbate at temperature $\mathrm{T}, \mathrm{kPa}$

q relation adsorbate per adsorbent, $\mathrm{kg} / \mathrm{kg}$

$\mathrm{q}^{\infty}$ maximum amount of adsorbate per adsorbent, $\mathrm{kg} / \mathrm{kg}$

$\mathrm{T}$ bed temperature, $\mathrm{K}$

$X$ mass amount of adsorbate in the anhydrous adsorbent, $\mathrm{kg} / \mathrm{kg}$

$X_{0}$ maximum amount of adsorbate in the anhydrous adsorbent, $\mathrm{kg} / \mathrm{kg}$

W volume of adsorbate in the unit mass of adsorbent, $\mathrm{cm}^{3} / \mathrm{g}$

$\mathrm{W}_{0}$ maximum volume of adsorbent per adsorbed mass, $\mathrm{cm}^{3} / \mathrm{g}$

\section{INTRODUCTION}

The increase of global energy consumption as well as the destruction of the ozone layer by CFC and HCFC has been the motivation for the development of new cooling technologies. Among those, adsorption, where instead of these refrigerants, solar energy is used, consists of an excellent alternative of cooling system.

The types of adsorption mechanisms determine the theoretical aspects of approach and equating of the phenomenon. For the case of volume filling of micropores (pore diameters smaller than $4 \mathrm{~nm}$, according to the classification of the IUPAC), the Dubinin-Astakhov (Dubinin, 1967), Eq. (1), cited by Oliveira et al. (2001), Silveira. Jr. (1990), Barbosa (1993) and Vodianitskaia (1984), assumes that the micropore is filled during the adsorption process considering the maximum volume per mass unit of adsorbent, W0, occupied by the adsorbate.

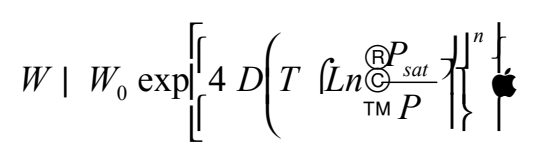

Another model known as Freundlich equation, Eq. (2), or the classic isotherm adsorption equation (Saha et al., 1995), commonly used to describe the equilibrium properties of the pair silica-gel/water. The Freundlich equation is simple, nevertheless it presents a good correlation with the experimental data for this pair (Cho and Kim, 1992; Chihara and Suzuki, 1983).

$$
q \quad q^{\mathrm{f}}\left(\frac{P}{P_{\text {sat }}}\right)^{\frac{1}{k}}
$$


The amount of vapor adsorbed by a sample of microporous solid is proportional to the mass of the sample and it depends on temperature and pressure of the bed, as well as on the nature of the solid (adsorbent) and the vapor (adsorbate). Therefore, the choice of an adsorbent will depend on the vapor to be adsorbed, in addition to the retention capacity of the adsorbent (kg adsorbate/ $\mathrm{kg}$ adsorbent).

The adsorption process will occur in a bed until it reaches equilibrium between the vapor pressure of the adsorbate and the pressure of the adsorbed stage. By alternating the equilibrium state (through temperature increase or pressure reduction) there occurs an inverse process, denominated desorption, reactivation or regeneration. In general, this adsorption-desorption cycle can be repeated many times without significantly altering the physical-chemical properties of the adsorbent.

The silica-gel is a highly porous solid produced from sulfuric acid and sodium silicate. It consists of porous particles with diameters varying between $2-20 \mathrm{~nm}$. Each $1 \mathrm{~m}^{3}$ of silica gel contains pores that if added would account for a surface area of about $2.8 \times 10^{7} \mathrm{~m}^{2}$ (Saha et al., 2000). The silica-gel has a great capacity to adsorb vapor water, of around 35 to $40 \%$ of its dry mass, along with low regeneration temperatures $(\mathrm{Ng}$ et al, 2001; Tahat, 2001). According to Tahat (2001), silica gel is safe, non corrosive, cheap, abundant and it has been widely used to its great adsorption capacity and chemical stability.

\section{EXPERIMENTS}

The experimental assembly (Fig. 1) consisted of a cell coated in stainless steel, containing vacuum flanges and sealing rings, vacuum pump, thermostatic bath to keep the silica temperature constant, volumetric bottle containing distilled water, four temperature sensors type Pt 100 along the cell, two vacuum pressure sensors, valves and vacuum connections. In order to obtain the pressure and temperature data, a data acquisition system model HP3852A Hewlett Packard and a remote microcomputer were used. The silica-gel used in white pearl granules is commercialized in Brazil by Odin Industry and Commerce LTDA.

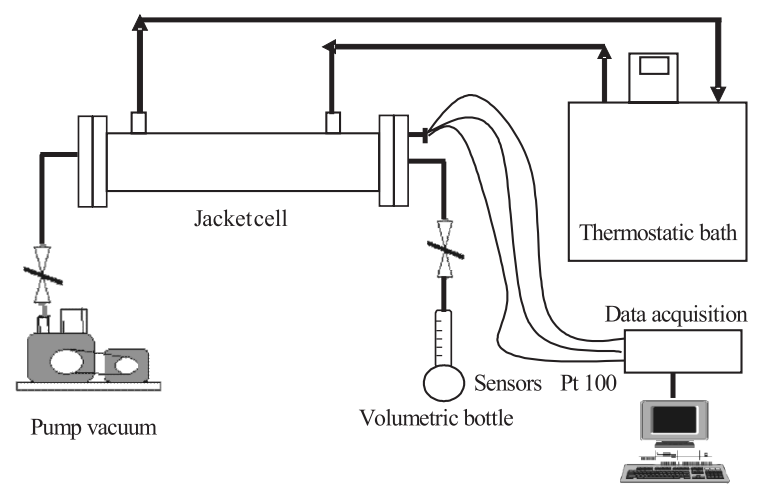

Figure 1. Experimental assembling for pair silica-gel/water characterization.

To build the isosters of the pair silica-gel/ water, the proposed model was the DubininAstakhov equation, Eq. (1), which according to Oliveira et al. (2001), may lead to Eq. (3), through a simple division by the adsorbate density. Posterior linearization (Eq. 4) indicates that by varying the pressure and temperature of the bed it is possible to estimate parameters $X_{0}, D$ e $n$. Thus, the experimental data obtained in the experiments were adjusted according to a method of curve fitting with the proposed model. Therefore, several isosters of the pair silica-gel/water may be built.

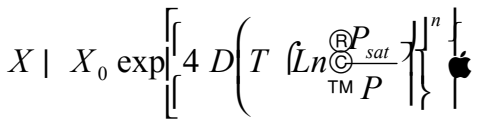

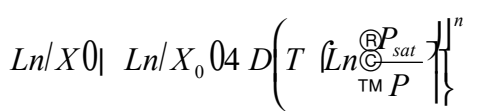

In a similar way, the Freundlich equation (Eq. 2) was also linearized. Equation (5), as well as Eq. 4, with varying temperature and pressure, estimates the values $q^{\infty}$ e $k$ and builds the isosters of the pair.

$$
\log (q) \quad \log \left(q^{\mathrm{f}}\right) \square \frac{1}{k} \log \left(\frac{P}{P_{\text {sat }}}\right)
$$

To obtain the experimental data, the silicagel was put into a jacketed cell together with temperature sensors and other connections. Firstly, the silica-gel desorption was carried out, through thermal oil heating $\left(125^{\circ} \mathrm{C}\right)$ heated in thermostatic bath and circulated through the jacket. In this phase, a valve connected to the coated cell was kept open until the bed temperature reached $120^{\circ} \mathrm{C}$. After that, the vacuum pump was turned on to remove formed vapor; the system was kept as such for 24 hours $\left(120^{\circ} \mathrm{C}\right.$ under pressure lower than $0.013 \mathrm{kPa}$ ). 
After the desorption phase and sequential bed cooling, the following procedures was adopted:

The valve connected to the bottle containing distilled water was opened and remained that way until a certain water amount had been adsorbed by the silica-gel bed. After the valve had been closed, thermal oil was circulated with different temperatures in order to condition the silica-gel bed temperature and the resulting pressures were measured.

\section{RESULTS AND DISCUSSION}

The amounts of water adsorbed by silica-gel were set in cumulative form, that is, for each new amount adsorbed, the previous amount of adsorbed water was added. The amounts are presented in Tab. 1.

In the end of the experiments, the saturated silica- gel was immediately weighted. With known values for the mass and the amount of adsorbed water, it was possible to calculate, by difference, the amount of dry silica-gel previously contained in the bed, in addition to the maximum capacity of the silica-gel adsorption (Tab. 2).

Table 1. Amount of adsorbed water for each condition.

\begin{tabular}{|c|c|c|}
\hline Condition & $\begin{array}{c}\text { Volume of water } \\
(\mathrm{mL})\end{array}$ & $\begin{array}{c}\text { Mass of adsorbed } \\
\text { water }(\mathrm{kg})\end{array}$ \\
\hline 1 & 30.14 & 0.030 \\
\hline 2 & 58.91 & 0.059 \\
\hline 3 & 108.91 & 0.109 \\
\hline 4 & 208.91 & 0.208 \\
\hline 5 & 408.91 & 0.407 \\
\hline 6 & 722.06 & 0.720 \\
\hline 7 & 932.56 & 0.930 \\
\hline
\end{tabular}

Table 2. Amount of dry silica-gel and maximum adsorption capacity.

\begin{tabular}{|c|c|c|c|}
\hline $\begin{array}{c}\text { Mass of } \\
\text { saturated } \\
\text { silica-gel } \\
(\mathrm{kg})\end{array}$ & $\begin{array}{c}\text { Mass of } \\
\text { adsorbed } \\
\text { water } \\
(\mathrm{kg})\end{array}$ & $\begin{array}{c}\text { Mass of dry } \\
\text { silica-gel } \\
(\mathrm{kg})\end{array}$ & $\begin{array}{c}\text { Maximum } \\
\text { mass } \\
\text { adsorption } \\
(\%)\end{array}$ \\
\hline 5.817 & 1.363 & 4.454 & 30.6 \\
\hline
\end{tabular}

Thus, the conditions for each isostere $(\mathrm{kg}$ of water $/ \mathrm{kg}$ of silica-gel) were calculated by a simple division of the amount of adsorbed water (kg) by the amount of dry silica-gel (Tab. 3).
Table 3. Relation $\mathrm{kg} / \mathrm{kg}$ of each isostere.

\begin{tabular}{|c|c|c|}
\hline Isostere & $\begin{array}{c}\text { Mass of adsorbed water } \\
(\mathrm{kg})\end{array}$ & $\begin{array}{c}\text { Relation } \\
(\mathrm{kg} \text { water/kg silica- } \\
\text { gel })\end{array}$ \\
\hline 1 & 0.030 & 0.007 \\
\hline 2 & 0.059 & 0.013 \\
\hline 3 & 0.109 & 0.024 \\
\hline 4 & 0.208 & 0.047 \\
\hline 5 & 0.407 & 0.092 \\
\hline 6 & 0.720 & 0.162 \\
\hline 7 & 0.930 & 0.209 \\
\hline
\end{tabular}

In order to estimate the parameters $X_{0}, D$ and $n$ of the Dubinin-Astakhov and the $q^{\infty}$ and $k$ of the Freundlich model, the Statistica 5.0 program was used. The obtained values are show in Tab. 4 .

Table 4. Model parameters found.

\begin{tabular}{|c|c|c|c|c|c|}
\hline \multirow{2}{*}{ Model } & \multicolumn{5}{|c|}{ Parameters } \\
\cline { 2 - 6 } & $X_{0}$ & $D$ & $n$ & $q^{\infty}$ & $k$ \\
\hline $\begin{array}{c}\text { Dubinin- } \\
\text { Astakhov }\end{array}$ & 0.301 & $2.26 \times 10^{-2}$ & 1.08 & $\mathrm{n} / \mathrm{a}$ & $\mathrm{n} / \mathrm{a}$ \\
\hline Freundlich & $\mathrm{n} / \mathrm{a}$ & $\mathrm{n} / \mathrm{a}$ & $\mathrm{n} / \mathrm{a}$ & 0.355 & 0.79 \\
\hline
\end{tabular}

The Dubinin-Astakhov model (Eq. 4) has given a good agreement with the data, with $\mathrm{R}^{2}=$ 0.991 in Fig. 2.

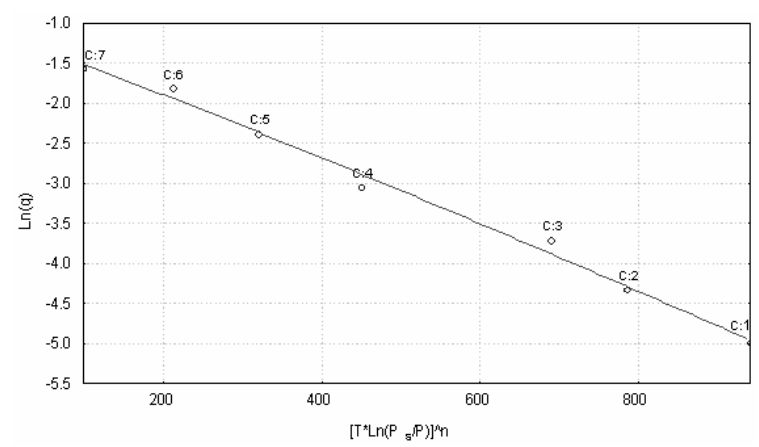

Figure 2. Adjustment of Dubinin-Astakhov model in linearized form: $y=(0.301)$ (0.00227). $(\mathrm{x})^{1.08}$ and $\mathrm{R}^{2}=0.991$

The Freundlich model (Eq. 5) has also showed a good correlation with the experimental data with $\mathrm{R}^{2}=0.993$ in Fig. 3. Since the two models yielded satisfactory data adjustment, the Freundlich model is preferable for the isosters construction, because it has a slightly higher correlation coefficient in addition to being simpler.

With the model and parameters defined, two isosters were traced and compared with other 
two from the works of Cho and Kim (1992) and Chihara and Suzuki (1983), who have used the same model. Figure 4 presents the comparison.

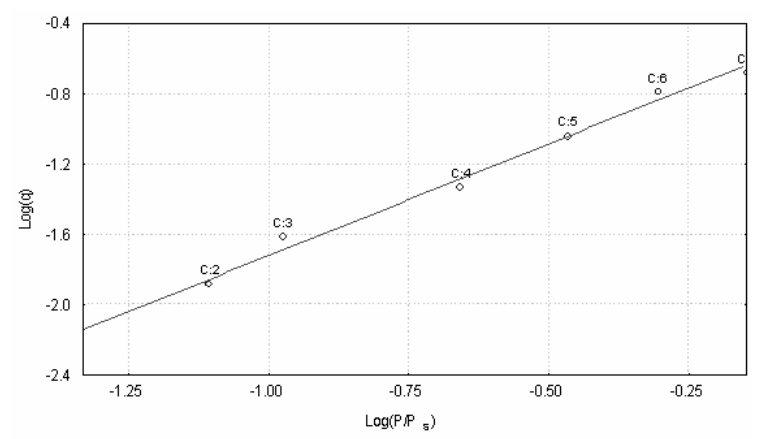

Figure 3. Adjustment of Freundlich model in linearized form: $y=(0.355)+(1 / 0.79)$. $(x)$ and $R^{2}$ $=0.993$

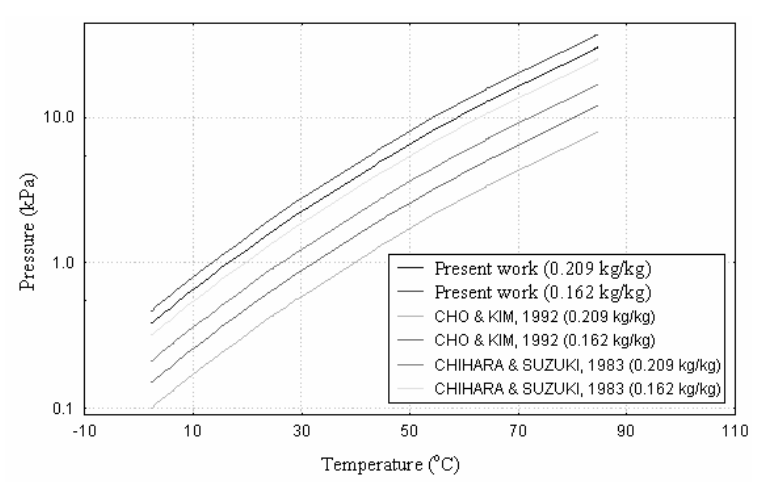

Figure 4. Comparison of isosteres for pair silicagel/water with the other authors.

Figure 5 presents the isosteres for the silicagel used in this work based on the Freundlich model and found parameters. Those isosters will enable the dimensioning of the bed adsorptions with the pair silica-gel/water and the cycle adsorption/desorption trace in an application, such as cooling, for instance.

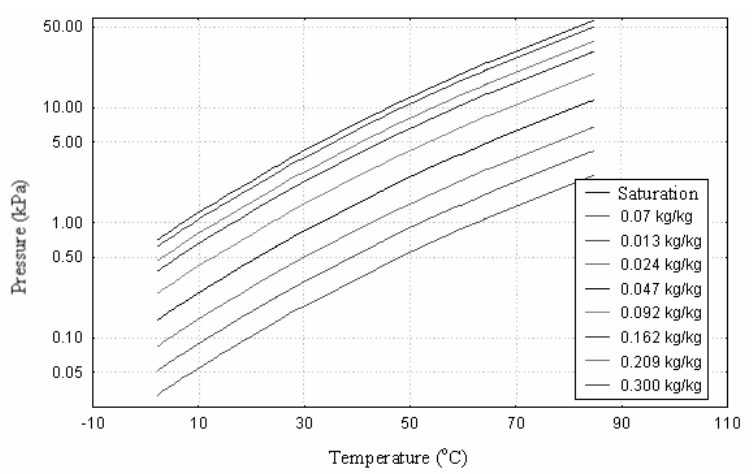

Figure 5. Isosters of pair silica-gel/water.

\section{CONCLUSIONS}

The knowledge of the pair behavior in different conditions of temperature and pressure and the relation to the adsorbate/adsorbent mass is essential in the project of refrigeration systems by adsorption. In the characterization of the pair silicagel/water in this work, the maximum experimental adsorption found was $30.6 \%$. According to the proposed models, the findings were $30.1 \%\left(X_{\theta}\right)$, by Dubinin-Astakhov and 35,5\% $\left(q^{\infty}\right)$ by Freundlich. Despite the difference, both proposed models present a good data adjustment with high correlation coefficients of 0.991 and 0.993 , respectively. Differences in the same isosters $(\mathrm{kg} / \mathrm{kg})$ among authors are common, since each one has worked with silica-gel from different producers.

\section{ACKNOWLEDGEMENTS}

The authors thank the financial support from Fundação de Amparo à Pesquisa do Estado de São Paulo (Fapesp) for the realization of this work.

\section{REFERENCES}

BARBOSA, G., 1993, Modelagem e Simulação de um Refrigerador Solar por Adsorção Física. Campinas. 75p. Doctoral Thesis, Fac. de Eng. de Alim., Univ. Est. de Campinas. Campinas, SP. (in Portuguese)

CHIHARA, K., SUZUKI, M., 1983, Air drying by pressure swing adsorption, Journal of Chemical Engineering of Japan, Vol.16, No.4, pp. 293-298.

CHO, S. H., KIM, J. N., 1992, Modeling of silica gel/water adsorption-cooling system, Energy, Vol. 17, No. 9, pp. 829-839.

DUBININ, M. M., 1967, Adsorption in micropores, Journal of Colloid and Interface Science, Vol. 23, pp. 487-499.

NG, K. C., CHUA, H. T., CHUNG, C. Y., LOKE, C.H., KASHIWAGI, T., AKISAWA, A., SAHA, B. B., 2001, Experimental investigation of the silicagel-water adsorption isotherm characteristics, Applied Thermal Engineering, Vol. 21, pp. 1631-1642.

OLIVEIRA, R. G., TAMAINOT-TELTO, Z., SILVEIRA Jr., V., 2001, Equilibrium characterization of carbon C119-ammonia and carbon c119-dimethyl ether pairs and application in adsorption refrigeration system design. Cong. Bras. de Eng. Mec. (COBEM). (in Portuguese) 
SAHA, B. B., BOELMAN, E. C., KASHIWAGI, T., 1995, Computer simulation of a silica gel-water adsorption refrigeration cycle-the influence of operating conditions on cooling output and COP, ASHRAE Transactions: Research, Vol. 101, No.1, pp. 348-357.

SAHA, B. B., AKISAWA, A., KASHIWAGI, T., 2000, Solar/waste heat driven two-stage adsorption chiller: the prototype, Renewable Energy, Vol. 23, pp. 93-101.

SILVEIRA Jr., V., 1990, Montagem e teste de desempenho de um refrigerador solar por adsorção física com produção de gelo. Doctoral Thesis, Fac. de Eng. de Alim., Univ. Est. de Campinas, Campinas, SP. (in Portuguese)

TAHAT, M. A., 2001, Heat-pump/energystore using silica gel and water as a working pair. Applied Energy, No. 69, pp. 19-27.

VODIANITSKAIA, P., 1984, Desenvolvimento Experimental de um Refrigerador Solar a Adsorção Utilizando o Par Frigorífico Gel de Sílica-Água. Doctoral Thesis, Fac. de Eng. Mec., Universidade Federal da Paraíba, João Pessoa, PB. (in Portuguese) 